\title{
Dexmedetomidine Protects Neural Stem Cells from Ketamine-Induced Injury
}

\author{
Pan Lu Shan Lei $^{\mathrm{a}}$ Weisong Lia Yang Lu ${ }^{\mathrm{a}} \quad$ Juan Zhenga Ning Wanga \\ Yongjun Xiaa, Haixia Lu $^{\mathrm{b}}$ Xinlin Chen ${ }^{\mathrm{b}}$ Yong Liu ${ }^{\mathrm{b}}$ Pengbo Zhang ${ }^{\mathrm{a}}$ \\ aDepartment of Anesthesiology, The Second Affiliated Hospital of Xi'an Jiaotong University, Xi'an, \\ Shaanxi, 'Institute of Neurobiology, National Key Academic Subject of Physiology of Xi'an Jiaotong \\ University, Xi'an, Shaanxi, 'Department of Anesthesiology, Affiliated Hospital of Chinese People's Armed \\ Police Engineering University, Xi'an, Shaanxi, China
}

\section{Key Words}

Dexmedetomidine $\cdot$ Ketamine $・$ Neural stem cells $•$ Neurotoxicity $•$ PI3K/Akt/GSK-3 $\beta$ pathway

\begin{abstract}
Background/Aims: Ketamine inhibits the proliferation of neural stem cells (NSCs) and disturbs normal neurogenesis. Dexmedetomidine provides neuroprotection against volatile anesthetic-induced neuroapoptosis and cognitive impairment in the developing brain. Whether it may protect NSCs from ketamine-induced injury remains unknown. In this study, we investigated the protective effects of dexmedetomidine on ketamine-exposed NSCs and explored the mechanisms potentially involved. Methods: Primary NSC cultures were characterized using immunofluorescence. Cell viability was determined using a Cell Counting Kit 8 assay. Proliferation and apoptosis were assessed with BrdU incorporation and TUNEL assays, respectively. Protein levels of cleaved caspase-3, phosphorylated protein kinase $B(p-A k t)$, and glycogen synthase kinase-3 $\beta$ ( $p-G S K-3 \beta$ ) were quantified using western blotting. Results: Ketamine significantly decreased NSC viability and proliferation and increased their apoptosis. Dexmedetomidine increased NSC proliferation and decreased their apoptosis in a dose-dependent manner. Furthermore, dexmedetomidine pretreatment notably augmented the viability and proliferation of ketamine-exposed NSCs and reduced their apoptosis. Moreover, dexmedetomidine lessened caspase- 3 activation and increased $p$-Akt and p-GSK-3 $\beta$ levels in NSCs exposed to ketamine. The protective effects of dexmedetomidine on ketamine-exposed NSCs could be partly reversed by the PI3K inhibitor LY294002. Conclusions: Collectively, these findings indicate that dexmedetomidine may protect NSCs from ketamine-induced injury via the PI3K/Akt/GSK-3ß signaling pathway.
\end{abstract}


Lu et al.: Developmental Neurotoxicity and Neuroprotection

\section{Introduction}

Ketamine is commonly used in pediatric anesthesia [1]. Recent studies have shown that ketamine inhibits the proliferation of neural stem cells (NSCs), disturbing normal neurogenesis $[2,3]$, and causes neurodegeneration and neuroapoptosis in the developing brain, ultimately leading to long-term neurocognitive dysfunctions [4-8]. These findings have obligated medical workers to reevaluate the use of ketamine in pediatric anesthetic practice and to search for possible protective measures.

The $\alpha_{2}$-adrenoceptor subtype is widely expressed during brain development [9]. It mediates the neurotrophic effects of norepinephrine and dendrite growth in cortical neurons during fetal cortical development $[10,11]$. Dexmedetomidine, an $\alpha_{2}$-adrenoceptor agonist, is an effective auxiliary medicine in clinical anesthesia and intensive care due to its anxiolytic, sedative, and analgesic activity. Dexmedetomidine can prevent neurodegeneration from cerebral ischemia and spinal injury $[12,13]$. Several recent studies have shown that dexmedetomidine has protective effects on isoflurane- and sevoflurane-induced neurodegeneration in the developing rat brain [14-16]. In pediatric practice, anesthesiologists preferentially select the combination of ketamine and dexmedetomidine to reduce the adverse effects of ketamine [17-19]. However, it remains unknown whether dexmedetomidine can attenuate ketamine-induced injury in NSCs.

The phosphatidylinositol 3-kinase (PI3K) and Akt pathway is a major cell signaling pathway that mediates signal transduction during normal cell physiological activities [20]. Activation of the PI3K/Akt signaling pathway has been reported to protect the brain from ischemia-reperfusion injury and ketamine-induced cortical neuronal apoptosis [3, 20-22]. Interestingly, the PI3K/Akt/GSK-3 $\beta$ signaling pathway is also involved in the protective effects of dexmedetomidine on isoflurane-induced neurotoxicity in the neonatal rat brain [23]. It is unclear if the PI3K/Akt/GSK-3 $\beta$ signaling pathway mediates the protective effects of dexmedetomidine on ketamine-exposed NSCs. In this study, we investigated the protective effects of dexmedetomidine on ketamine-induced injury of NSCs and proposed that PI3K/ Akt/GSK-3 $\beta$ signaling might be involved in this protection.

\section{Materials and Methods}

Animals

Timed-pregnant Sprague-Dawley rats were provided by the Experimental Animal Center of Xi'an Jiaotong University (Certificate No. 22-9601018). All animal studies complied with the regulations of the Animal Care and Use Committee of Xi'an Jiaotong University and the National Institutes of Health Guide for the Care and Use of Laboratory Animals (NIH Publications No. 80-23). Pregnant rats were housed in a 12-h light/dark cycle with free access to food and water.

\section{Cell culture}

NSC isolation procedures were conducted as described in our previously reported methods [24]. Briefly, 8 to 12 rat fetuses at embryonic day 18 (E18) were obtained from timed-pregnant rats under sterile conditions. All of the anterior cortices were extracted from the fetuses, cut into pieces, and enzymatically digested with accutase (Sigma-Aldrich, St. Louis, MO, USA) for $5 \mathrm{~min}$ at $37^{\circ} \mathrm{C}$. The cell pellets were resuspended in DMEM/F12 (GIBCO, L.A., CA, USA) proliferation medium with $20 \mathrm{ng} / \mathrm{ml}$ of epidermal growth factor (EGF; GIBCO) and basic fibroblast growth factor (bFGF, GIBCO) and 2\% $\mathrm{N}_{2}, 1 \% \mathrm{~B} 27$, and $100 \mathrm{U} / \mathrm{ml}$ penicillin and streptomycin (GIBCO). The cell suspensions were seeded in 24-well plates precoated with poly-L-lysine (Sigma-Aldrich) or in 96 -well plates and cultured at $37^{\circ} \mathrm{C}$ in an atmosphere of $5 \% \mathrm{CO}_{2}$. Half of the culture medium was replaced every 3 days. After 5-7 days in culture, the neurospheres were dissociated into a cell suspension by incubation with accutase (Sigma-Aldrich) for $5 \mathrm{~min}$. The cells were seeded at a density of $2 \times 10^{5}$ cells $/ \mathrm{ml}$. For differentiation assessment, the cells from passage 1 of neurospheres were seeded at a density of $1 \times 10^{4}$ cells $/ \mathrm{ml}$ in 24 -well plates and cultured in basal medium with $10 \%$ fetal bovine serum (FBS) for $4 \mathrm{~h}$. Afterward, the medium was replaced with complete medium to allow differentiation for 7 days. 


\section{Cellular Physiology Cell Physiol Biochem 2018;47:1377-1388 and Biochemistry Published \begin{tabular}{l|l} 
DOI: 10.1159/000490823 & $\begin{array}{l}\text { (c) } 2018 \text { The Author(s). Published by S. Karger AG, Basel } \\
\text { www.karger.com/cpb }\end{array}$
\end{tabular}}

Lu et al.: Developmental Neurotoxicity and Neuroprotection

Protocol

The primary cultured cells were randomly divided into five groups: control (C), dexmedetomidine (D), ketamine (K), dexmedetomidine plus ketamine (DK), and dexmedetomidine plus ketamine plus PI3K inhibitor (LY294002) (LDK). The control group received no drug treatment. The cells in the dexmedetomidine group were incubated with different concentrations of dexmedetomidine $(0.1 \mu \mathrm{M}, 1.0 \mu \mathrm{M}, 10 \mu \mathrm{M}, 20 \mu \mathrm{M})$ for $24 \mathrm{~h}$, whereas those in the ketamine group were treated with $100 \mu \mathrm{M}$ ketamine for $24 \mathrm{~h}$. The cells in the DK group were pretreated with different concentrations of dexmedetomidine $(0.1 \mu \mathrm{M}, 1.0 \mu \mathrm{M}, 10 \mu \mathrm{M}, 20$ $\mu \mathrm{M}$ ) for 30 min prior to incubation with $100 \mu \mathrm{M}$ ketamine for $24 \mathrm{~h}$. The cells in the LDK group were first treated with $20 \mu \mathrm{M} \mathrm{LY294002} \mathrm{for} 2 \mathrm{~h}$, then with $20 \mu \mathrm{M}$ dexmedetomidine for $30 \mathrm{~min}$, and finally with 100 $\mu \mathrm{M}$ ketamine for $24 \mathrm{~h}$.

\section{Immunofluorescence and nuclear staining}

The cultured cells and their proliferation potency were characterized and tested by immunofluorescence analysis. The cells were treated with $10 \mu \mathrm{g} / \mathrm{l}$ of BrdU for the last $4 \mathrm{~h}$ of the drug treatments and fixed with $4 \%$ paraformaldehyde for $30 \mathrm{~min}$ at room temperature. After washing, the cells were permeabilized with $0.3 \%$ Triton X-100 for 10 min and treated with blocking buffer ( $5 \%$ goat serum) for $1 \mathrm{~h}$ prior to incubation with the primary antibodies overnight at $4^{\circ} \mathrm{C}$. The primary antibodies used were as follows: mouse monoclonal anti-nestin antibody (1:500; Millipore, Billerica, MA, USA), rabbit polyclonal anti-glial fibrillary acidic protein (GFAP) antibody (1:1000; Sigma-Aldrich), and mouse monoclonal anti- $\beta$-tubulin III antibody (1:1000; Sigma-Aldrich) for NSC identification; rabbit polyclonal anti-N-methyl-D-aspartate receptor 1 (NMDAR1) antibody (1:100; Abcam, Cambridge, MA, USA) and goat polyclonal anti- $\alpha$-2A adrenergic receptor antibody (1:100; Abcam) to examine the expressions of NMDAR1 and $\alpha$-2A adrenergic receptor in NSCs, respectively; and rat monoclonal anti-BrdU (1:1000; Abcam) to detect proliferating cells. Cells were washed and incubated with secondary antibodies (fluorescein isothiocyanate [FITC] or tetramethylrhodamine isothiocyanate [TRITC]-conjugated IgG) for $2 \mathrm{~h}$ followed by incubation with 4',6'-diamidino-2'-phenylindole (DAPI; 1:1000; Abcam) for $10 \mathrm{~min}$ at room temperature. The slides were rinsed with PBS and imaged using a laser confocal microscope (TSC SP2, Leica, Mannheim, Germany). At least three independent experiments were conducted per assay.

\section{TUNEL fluorescent assay}

To detect NSC apoptosis in the different treatment groups, cells were labeled with TUNEL. The procedure was conducted in accordance with the instructions of the In Situ Cell Death Detection Kit (Roche, Mannheim, Germany). The slides were protected from light during the experiment and nuclei were counterstained with DAPI. TUNEL-positive cells were analyzed as for the immunofluorescent staining.

\section{Measurement of cell viability}

Cell viability was tested by a Cell Counting Kit 8 (CCK8) assay (Dojindo Molecular Technologies, Gaithersburg, MD, USA) according to the manufacturer's protocol. Briefly, each well was incubated with $10 \mu \mathrm{l}$ of 5 $\mathrm{mg} / \mathrm{ml} \mathrm{CCK8}$ solution at $37^{\circ} \mathrm{C}$ for the last $4 \mathrm{~h}$ of drug treatments. The CCK8 solution was then removed and $200 \mu \mathrm{l}$ of dimethyl sulfoxide was added to dissolve the formazan. The optical density was detected with a plate reader at $450 \mathrm{~nm}$.

\section{Western blot analysis}

Western blot analysis was used to detect caspase-3 cleavage and phosphorylation of Akt and GSK$3 \beta$ as described previously [25]. Equal amounts of cell lysates were used for the analyses. Proteins were separated by sodium dodecyl sulfate-polyacrylamide gel electrophoresis and transferred to nitrocellulose membranes. Membranes were blocked for $2 \mathrm{~h}$ at room temperature and incubated with primary antibodies overnight at $4{ }^{\circ} \mathrm{C}$. The following primary antibodies were used: mouse monoclonal anti- $\beta$-actin antibody (as a control, internal standard, 1:10, 000; Cell Signaling Technology Inc., Beverly, MA, USA), rabbit polyclonal anti-caspase-3 antibody (1:1000; Cell Signaling Technology) to detect full-length caspase-3 (35-40 kDa) and caspase-3 fragments (17-20 kDa), rabbit polyclonal anti-phosphorylated Akt antibody (p-Akt, 1:1000; Cell Signaling Technology), rabbit polyclonal anti-phosphorylated GSK-3 $\beta$ antibody (p-GSK-3 $\beta, 1: 1000$; Cell Signaling Technology), mouse polyclonal anti-Akt antibody (Akt, 1:1000; Cell Signaling Technology), and mouse polyclonal anti-GSK-3 $\beta$ antibody (GSK-3 $\beta, 1: 1000$; Cell Signaling Technology). After being thoroughly 


\section{Cellular Physiology Cell Physiol Biochem 2018;47:1377-1388 \begin{tabular}{ll|l} 
DOI: 10.1159/000490823 & $\begin{array}{l}\text { O 2018 The Author(s). Published by S. Karger AG, Basel } \\
\text { www.karger.com/cpb }\end{array}$
\end{tabular}}

Lu et al.: Developmental Neurotoxicity and Neuroprotection

washed, the membranes were incubated with secondary antibody (1:5000; Santa Cruz Biotechnology, Santa Cruz, CA, USA) for $2 \mathrm{~h}$ at room temperature. Luminescent signals were detected with a CCD camera and the data obtained were analyzed and stored.

\section{Cell counting and statistical analysis}

$\mathrm{Nestin}^{+} / \mathrm{DAPI}^{+}$cells, BrdU ${ }^{+} / \mathrm{DAPI}^{+}$cells, and $\mathrm{TUNEL}^{+} / \mathrm{DAPI}^{+}$cells were counted in a randomized blinded fashion. Five to seven sections from each well were randomly selected for quantification. For the TUNEL staining, only densely labeled cells were considered positive [26]. At least 200 cells per section were counted and the average number of cells in each section was approximately 350. At least three independent experiments were performed. The percentage of positive cells is presented as the ratio of positive cells to all cells $\left(\mathrm{DAPI}^{+}\right)$. The data are presented as the mean \pm SEM and analyzed by the Student's $t$ test or one-way analysis of variance (ANOVA). $p<0.05$ indicated a significant difference.

\section{Results}

\section{Identification of NSCS}

Nestin, a cytoskeletal intermediate filament protein, is a marker for NSCs and neural progenitor cells. To characterize the cultured cells, we first performed immunofluorescent staining with nestin. Nestin-positive cells comprised approximately $95-98 \%$ of all neurosphere-forming cells (Fig. 1A). Because NSCs have the ability to differentiate into neurons and astrocytes, we seeded the cells in complete medium with FBS to allow their differentiation for 7 days and observed that cultured cells expressed $\beta$-tubulin III, a specific marker for neurons (Fig. 1B, arrowhead), and GFAP, a specific marker for astrocytes (Fig. 1B, arrow). Thus, most of the cells in this study were NSCs. To verify the expressions of NMDAR and $\alpha_{2 A}$ ad-

Fig. 1. Identification of neural stem cells. (A) Immunostaining of cells in a neurosphere for the neural stem cell (NSC) marker nestin (red, arrow) and DNA marker DAPI (blue). (B) Representative immunofluorescent images of the cultures at day 7. Double immunofluorescent staining of cell cultures for $\beta$-tubulin III (neuronal marker, green) and GFAP (astrocyte marker, red). The nuclei were counterstained with DAPI (blue). The cells differentiated into neurons (arrowhead) and astrocytes (arrow). (C) Double-staining of NMDAR1 (green) and nestin (red). The nuclei were counterstained with DAPI (blue). Double-stained cells are indicated with arrows. (D) Double-staining of $\alpha_{2 \mathrm{~A}}$-adrenergic receptor (green) and nestin (red). The nuclei were counterstained with DAPI (blue). Double-stained cells are indicated with arrows. Scale bar, $50 \mu \mathrm{m}$.
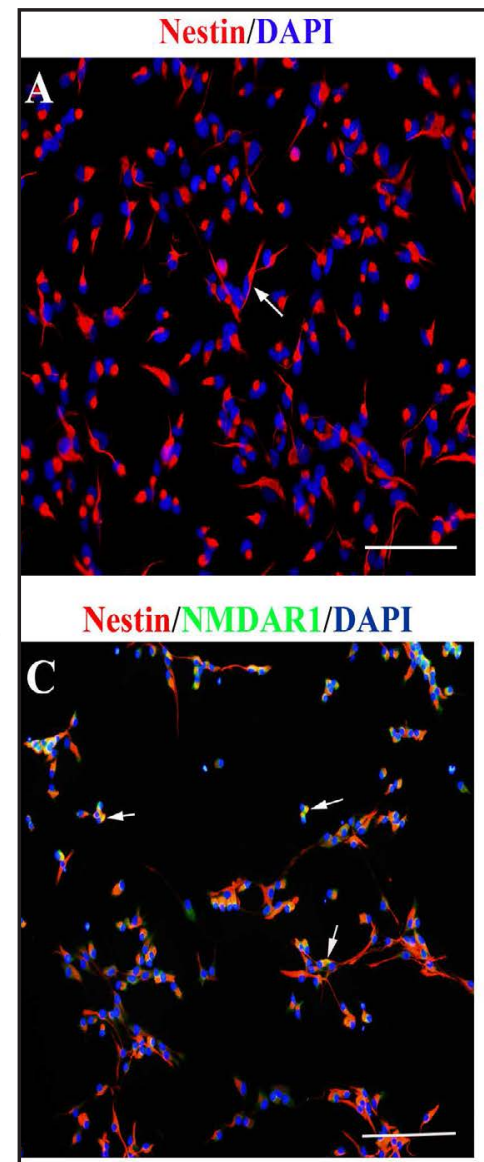
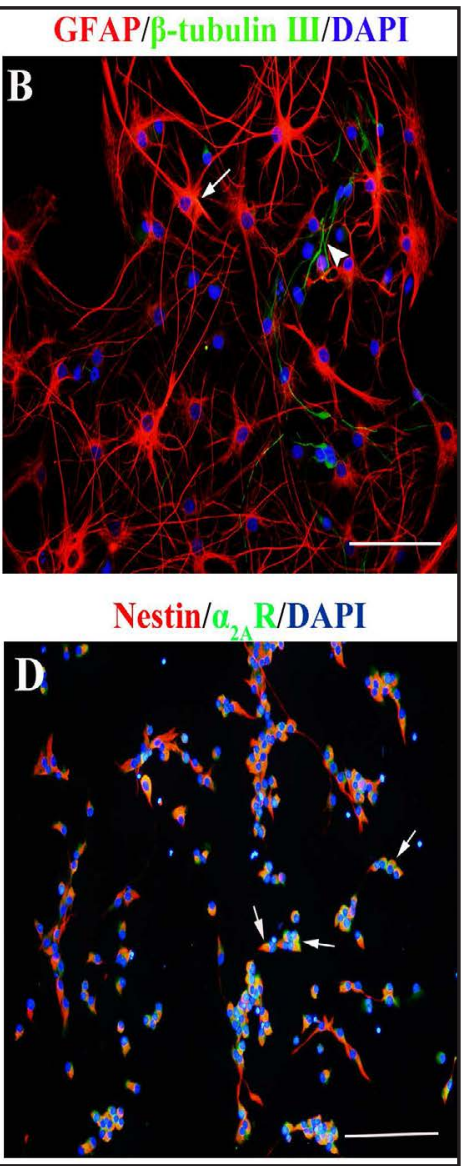
Lu et al.: Developmental Neurotoxicity and Neuroprotection

renergic receptors in NSCs, we performed double-staining of the cells using antibodies targeting NMDAR1 and nestin or $\alpha_{2 \mathrm{~A}}$ adrenergic receptor and nestin, respectively. The results show that the NSCs expressed NMDAR1 (Fig. 1C, arrow) and $\alpha_{2 \mathrm{~A}}$ adrenergic receptor (Fig. 1D, arrow).

\section{Toxic effects of ketamine on NSCS}

We used proliferation, apoptosis, and viability assays to evaluate the toxic effects of ketamine on NSCs. Ketamine exposure $(100 \mu \mathrm{M}, 24 \mathrm{~h})$ decreased the percentage of BrdU-positive cells ( $43 \%$ vs. $62.9 \%$ in the control group, $\mathrm{n}=18$ per group, $p<0.01$, Student's $t$ test) (Fig. 2A and Fig. 2B, compare the black and white bars), indicating that ketamine (100 $\mu \mathrm{M}, 24 \mathrm{~h})$ might inhibit NSC proliferation. Ketamine treatment also increased the percentage of TUNEL-positive cells in NSCs (3.0\% vs. $2.2 \%$ in the control group, $\mathrm{n}=13$ per group, $p<0.01$, Student's $t$ test) (Fig. $2 \mathrm{~A}$ and Fig. 2C, compare the black and white bars), suggesting that ketamine can induce NSC apoptosis. Moreover, ketamine exposure $(100 \mu \mathrm{M}, 24 \mathrm{~h})$ significantly decreased cell viability as assessed by measuring the cell concentration (optical density: 0.365 vs. 1.18 in the control group, $\mathrm{n}=6 \mathrm{per}$ group, $p<0.01$, Student's $t$ test) (Fig. 4A, compare the black and white bars).

Fig. 2. The effects of ketamine and dexmedetomidine on neural stem cell proliferation and apoptosis. The cells were treated with 100 $\mu \mathrm{M}$ ketamine and different concentrations of dexmedetomidine (Dex) for 24 h. (A) Representative images of cell proliferation (upper panel, BrdU staining, red) and apoptosis (lower panel, TUNEL staining, green). The nuclei were counterstained with DAPI (blue). Scale bar, $50 \mu \mathrm{m}$. (B) The percentages of $\mathrm{BrdU}^{+}$cells in the different groups are expressed as the amount of $\mathrm{BrdU}^{+}$cells relative to all cells (DAPI ${ }^{+}$( $\mathrm{n}=18$ per group). (C)

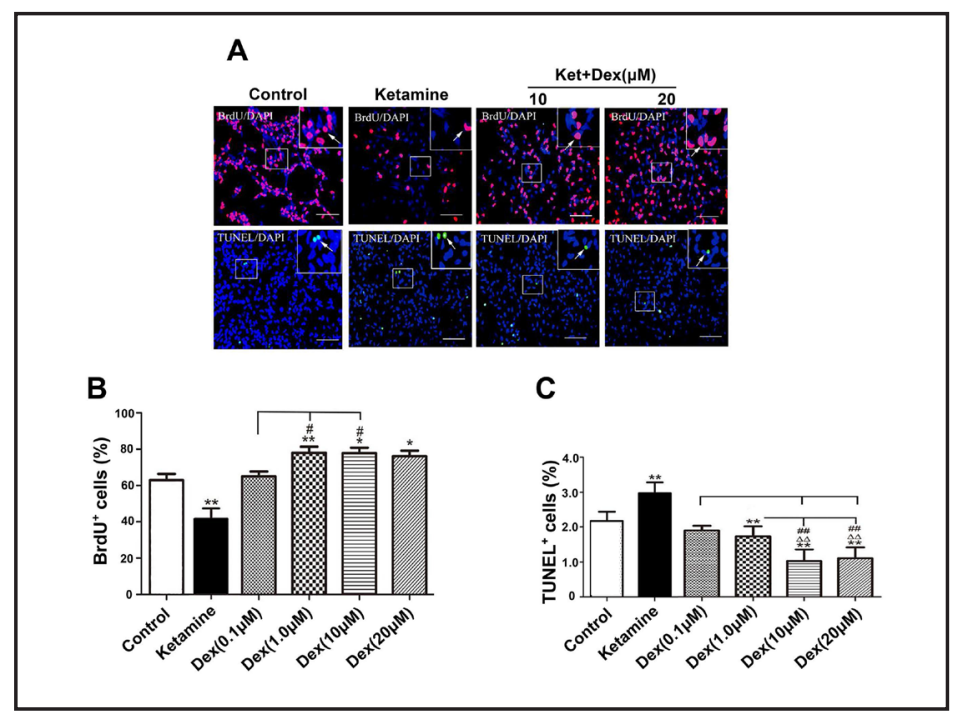
The percentages of $\mathrm{TUNEL}^{+}$cells in the different groups are expressed as the amount of $\mathrm{TUNEL}^{+}$cells relative to all cells (DAPI $\left.{ }^{+}\right)(\mathrm{n}=13$ per group). Data are shown as the mean \pm SEM. ${ }^{*} \mathrm{p}<0.05$ and ${ }^{* *} \mathrm{p}<0.01$ vs. control; $\# \mathrm{p}<0.05$ and $\# \# \mathrm{p}<0.01$ vs. the dexmedetomidine $(0.1 \mu \mathrm{M})$ group; $\Delta \Delta \mathrm{p}<0.01$ vs. the dexmedetomidine $(1.0 \mu \mathrm{M})$ group.

Fig. 3. Dexmedetomidine protects neural stem cells from ketamineinduced injury. The cells were pretreated with different concentrations of dexmedetomidine (Dex) for $30 \mathrm{~min}$ in the absence or presence of LY294002 prior to ketamine (Ket) exposure. (A) The amount of $\mathrm{BrdU}^{+}$cells is expressed as the percentage of all cells (DAPI ${ }^{+}$) exposed to the differ-

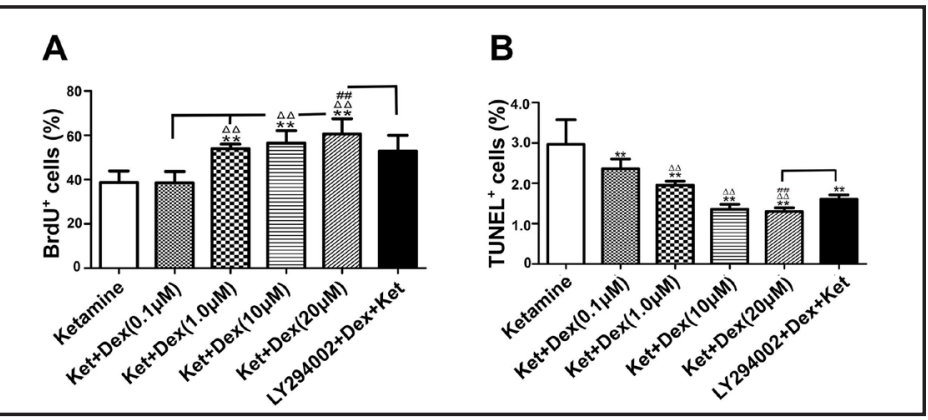
ent treatments ( $\mathrm{n}=18$ per group). (C) The amount of TUNEL ${ }^{+}$cells is expressed as the percentage of all cells $\left(\mathrm{DAPI}^{+}\right)$exposed to the different treatments $\left(\mathrm{n}=12\right.$ per group). Data are shown as the mean $\pm \mathrm{SEM} .{ }^{* *} \mathrm{p}<0.01$ vs. the ketamine group; $\Delta \Delta \mathrm{p}<0.01$ vs. the ketamine plus dexmedetomidine $(0.1 \mu \mathrm{M})$ group; \#\#p<0.01 vs. the ketamine plus dexmedetomidine plus LY294002 group. 
Lu et al.: Developmental Neurotoxicity and Neuroprotection

The NSCs were also subjected to western blot analysis at the end of the treatments. Ketamine exposure $(100 \mu \mathrm{M}, 24 \mathrm{~h})$ induced a visible increase in cleaved caspase-3 (caspase-3 fragment) compared with the control group (Fig. 4E, compare lanes 3 and 1). Quantification of the ratio of the caspase- 3 fragment to the full-length caspase-3 (FL-caspase-3) further supported this notion (299\% in ketamine-treated NSCs vs. $100 \%$ in control cells, $\mathrm{n}=3$ per group, $p<0.05$, oneway ANOVA) (Fig. 4B, compare the black and white bars). In summary, these data suggest that ketamine treatment may decrease NSC proliferation and induce apoptosis, resulting in reduced cell viability.

\section{Effects of dexmedetomidine on NSCs}

To determine the optimal dose of dexmedetomidine, we first tested the effects of different concentrations of dexmedetomidine $(0.1 \mu \mathrm{M}, 1.0 \mu \mathrm{M}, 10 \mu \mathrm{M}$, and $20 \mu \mathrm{M})$ on NSC proliferation and apoptosis using immunofluorescence. Quantification of the images illustrated that dexmedetomidine dose-dependently increased the percentage of BrdU-positive cells (65.0\%, 78.0\%, $77.8 \%$, and $76.2 \%$, respectively, vs. $62.9 \%$ in the control group; $\mathrm{n}=12$ per group, $p<0.01$, oneway ANOVA) and decreased the percentage of TUNEL-positive cells $(1.9 \%, 1.8 \%, 1.1 \%$, and $1.1 \%$, respectively, vs. $2.2 \%$ in control group; $\mathrm{n}=13$ per group, $p<0.01$, one-way ANOVA) (Fig. 2B and Fig. 2C, compare the gray and white bars). Dexmedetomidine treatment did not affect cell viability as assessed by cell concentration (optical density: 1.09 vs. 1.18 of the control group, $p>0.05$, Student's $t$ test) (Fig. 4A, compare the gray and white bars) or caspase-3 activation in NSCs (76\% vs. $100 \%$ in the control group, $\mathrm{n}=3$ per group, $p>0.05$, one-way ANOVA) (Fig. 4B and Fig. 4E,

Fig. 4. The PI3K/Akt/GSK-3 $\beta$ pathway is involved in the protective effects of dexmedetomidine on ketamine-exposed neural stem cells. The cells were treated with $100 \mu \mathrm{M}$ ketamine or $20 \mu \mathrm{M}$ dexmedetomidine in the absence or presence of LY294002. C, D, K, DK, and LDK represent control, dexmedetomidine, ketamine, dexmedetomidine plus ketamine, and dexmedetomidine plus ketamine plus LY294002, respectively. (A) Effects of the different treatments on NSC viability ( $\mathrm{n}=6$ per group). (B) Effects of the different treatments on caspase-3 cleavage (activation) ( $n=3$ per group). Caspase- 3 activation is expressed as the amount of cleaved caspase-3 (caspase-3 fragment) relative to full-length caspase-3 (FL-caspase-3) and normalized to control. (C) Effects of the different treatments on Akt activation ( $\mathrm{n}=3$ per group). Akt activation is expressed as the amount of phosphorylated Akt relative to total Akt and normalized to control. (D) Effects of the different treatments on GSK-3 $\beta$ inactivation ( $n=3$ per group). GSK-3 $\beta$ inactivation is expressed as the amount of phosphorylated GSK-3 $\beta$ relative to total GSK-3 $\beta$ and normalized to control. Equal amounts of protein extracts were analyzed by western blot. The optical densities of the target bands were normalized to $\beta$-actin. Data are shown as the mean \pm SEM. ${ }^{*} \mathrm{p}<0.05$, ${ }^{* *} \mathrm{p}<0.01$ vs. control; $\Delta \mathrm{p}<0.05, \Delta \Delta \mathrm{p}<0.01$ vs. DK.
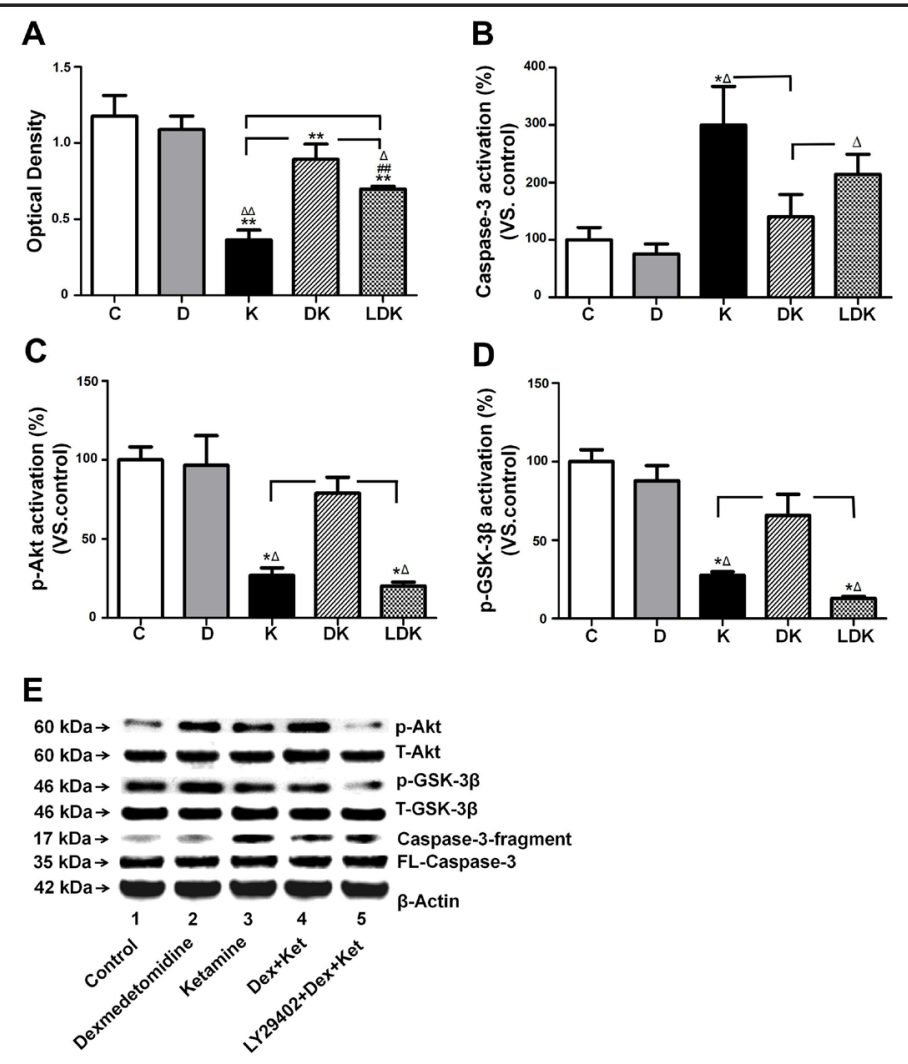
Lu et al.: Developmental Neurotoxicity and Neuroprotection

compare the gray and white bars). These results indicate that dexmedetomidine may increase NSC proliferation and decrease apoptosis in a dose-dependent manner. Therefore, we selected 20 $\mu \mathrm{M}$ dexmedetomidine as the best dose for further experiments.

\section{Dexmedetomidine protects NSCs from ketamine-induced toxicity}

We next assessed the effect of pretreatment with dexmedetomidine on ketamine-exposed NSCs. Dexmedetomidine pretreatment dose-dependently increased the percentage of BrdU-positive cells (39.6\%, 53.9\%, 56.5\%, and $60.6 \%$ in the $0.1 \mu \mathrm{M}, 1.0 \mu \mathrm{M}, 10 \mu \mathrm{M}$, and $20 \mu \mathrm{M}$ dexmedetomidine plus ketamine groups, respectively, vs. $39.5 \%$ in the ketamine group; $\mathrm{n}=15$ per group, $p$ $<0.01$, one-way ANOVA) (Fig. 2A and Fig. 3A) and cell viability (optical density: 0.89 vs. 0.36 in the control group, $\mathrm{n}=6$ per group, $p<0.01$, one-way ANOVA) (Fig. 4A, compare the hatched and black bars). Moreover, dexmedetomidine pretreatment of ketamine-exposed NSCs decreased the percentage of TUNEL-positive cells $(2.4 \%, 2.0 \%, 1.4 \%$, and $1.3 \%$, respectively, vs. $3.0 \%$ in the ketamine group, $\mathrm{n}=12$ per group, $p<0.01$, one-way ANOVA) (Fig. 2A and Fig. 3B) and caspase-3 activation ( $140 \%$ vs. $299 \%$ in ketamine-treated NSCs, $\mathrm{n}=3$ per group, $p<0.05$, one-way ANOVA) (Fig. 4B and Fig. 4E, compare the hatched and black bars). These results suggest that dexmedetomidine pretreatment may alleviate the adverse effects caused by ketamine exposure.

The PI3K/Akt/GSK-3ß pathway is involved in the protective effects of dexmedetomidine on ketamine-injured NSCs

We then examined whether the PI3K/Akt/GSK-3 $\beta$ pathway mediated the protective effects of dexmedetomidine on ketamine-injured NSCs. We incubated NSCs with the PI3K inhibitor LY294002 $(20 \mu \mathrm{M}, 2 \mathrm{~h})$ prior to dexmedetomidine pretreatment $(20 \mu \mathrm{M}, 30 \mathrm{~min})$ and ketamine exposure $(100 \mu \mathrm{M}, 24 \mathrm{~h})$. Quantification of western blotting results revealed that ketamine exposure resulted in lower p-Akt and p-GSK-3 $\beta$ levels in NSCs compared with the control group $(27 \%$ vs. $100 \%, 28 \%$ vs. $100 \%$, respectively; $\mathrm{n}=3$ per group, $p<0.05$, one-way ANOVA) (Fig. $4 \mathrm{C}$ and Fig. $4 \mathrm{D}$, compare the black and white bars, Fig. 4E, compare lanes 3 and 1); this decrease was partially restored by dexmedetomidine pretreatment to approximately $80 \%$ and $66 \%$, respectively (Fig. 4C and Fig. 4D, compare the hatched, black, and white bars, Fig. 4E, compare lanes 4, 3, and 1). Furthermore, the PI3K inhibitor LY294002 reversed the protective effects of dexmedetomidine, causing an approximate 75\% decrease in Akt phosphorylation and an approximately $80 \%$ decrease in GSK-3 $\beta$ phosphorylation (Fig. 4C, compare the grid and hatched bars, Fig. 4E, compare lanes 5 and 4). Likewise, LY294002 attenuated the effects of dexmedetomidine on the cell proliferation, apoptosis, and viability of ketamine-exposed NSCs (Fig. 3, black bar, Fig. 4A, compare the grid, hatched, and black bars). Collectively, these data show that dexmedetomidine may attenuate the toxic effects of ketamine on NSCs via the PI3K/Akt/GSK-3 $\beta$ signaling pathway.

\section{Discussion}

This study demonstrated that dexmedetomidine pretreatment attenuated ketamineinduced changes in cell viability, proliferation, and apoptosis and reversed the ketamineinduced reduction in Akt and GSK-3 $\beta$ phosphorylation in NSCs. In addition, the PI3K inhibitor LY294002 blocked the protective effects of dexmedetomidine on the ketamine-induced changes. These results suggest that dexmedetomidine may protect NSCs from ketamine-induced injury via the PI3K/Akt/GSK-3 $\beta$ pathway.

NSCs can proliferate and differentiate into neurons and glial cells and are thus critical for normal neurogenesis and gliogenesis during brain development [27]. The developing brain experiences a critical period called the brain growth spurt, which begins in humans in the last third trimester of pregnancy and lasts approximately 2 years after birth. However, in rodents, the brain growth spurt starts at the end of pregnancy and extends for the first 21 postnatal days [28]. Therefore, we investigated the effects of ketamine on NSCs obtained from embryonic day 18 rat anterior cortices. Recent studies have shown that ketamine alters the proliferation and differentiation of NSCs [29]. However, the effects of ketamine on NSCs were unclear. 
Previous studies have found both dose- and time-dependent neurotoxic effects of ketamine. Prolonged exposure (24-48 h) and high concentrations ( $>10 \mu \mathrm{M})$ of ketamine caused deleterious effects, unlike shorter exposure times or lower doses $[1,30]$. The concentration threshold to induce neuroapoptosis was not precisely defined in these studies but was somewhere in the 10 to $50 \mu \mathrm{M}$ range. However, lower doses had to be administered continuously for at least $48 \mathrm{~h}$ to cause harmful effects. Having considered both the dose and duration, we exposed NSCs to $100 \mu \mathrm{M}$ ketamine for $24 \mathrm{~h}$ to establish a ketamine injury model; this dosage was also based on the clinically relevant dose of ketamine. In the present study, we showed that ketamine decreased NSC viability and proliferation and increased apoptosis, which is consistent with previous studies [2,31].

NMDA receptor, a glutamate receptor subtype, plays an important role in brain development [32]. Activation of NMDA receptors can induce apoptosis in neurons [33]. It is also evident that NSCs can respond directly to manipulations caused by NMDA receptor antagonists, indicating that functional NMDA receptor is expressed on NSCs [34, 35]. In the present study, we showed that NSCs expressed NMDA receptors. Moreover, both in vivo and in vitro studies have reported that NMDA receptor is involved in the modulation of NSC activation and proliferation ([36-39], reviewed in [40]). As an antagonist of noncompetitive NMDA receptor, ketamine induces neuroapoptosis via a compensatory upregulation of NMDA receptor that leads to NMDA receptor dysfunction, which results in calcium overload and production of reactive oxygen species [1,30]. NMDA receptor activation also induces PI3K/Akt signaling [41], which contributes to NMDA-mediated neuroprotection [42]. Recently, it has been reported that activation of PI3K/Akt/GSK-3 $\beta$ signaling had a protective effect on ketamine-induced neuroapoptosis [21, 43-45]. Moreover, Liu et al. reported that lithium, an inhibitor of GSK$3 \beta$, could attenuate ketamine-induced neuroapoptosis [46]. Interestingly, lithium carbonate is an important therapeutic drug for psychosis while abuse of ketamine may induce psychosis [47]. All of these findings suggest that the toxic effect of ketamine is at least partly mediated via the PI3K/Akt/GSK-3 $\beta$ pathway. Even though the underlying mechanism remains unclear, it is certainly worth further investigation. Elucidation of this mechanism may lead to new methods for the prevention and/or treatment of anesthetic-induced neurotoxicity. In the present study, we observed a significant decrease in p-Akt and p-GSK-3 $\beta$ levels in ketamine-injured NSCs. These findings suggest that the PI3K/Akt/GSK-3 $\beta$ pathway may be involved in the neurotoxic effects of ketamine.

In contrast to ketamine, dexmedetomidine has neuroprotective effects [12, 13, 48-50], especially on anesthetic(isoflurane and sevoflurane)-induced neurodegeneration and neuroapoptosis in the developing rat brain $[15,16,51,52]$. However, there are only a few studies of the effects of dexmedetomidine on NSCs in vitro. Our study demonstrated the potential protective effects of $20 \mu \mathrm{M}$ dexmedetomidine on NSCs exposed to ketamine. We showed that dexmedetomidine treatment increased the proliferation of NSCs and inhibited their apoptosis in a dose-dependent manner. The effect was observed at $0.1 \mu \mathrm{M}$ (a clinically relevant concentration) $[53,54]$ and was most pronounced at $20 \mu \mathrm{M}$. Although some patients, especially pediatric patients, have higher requirements and better tolerance for dexmedetomidine (up to 10 times of the clinical concentration) $[55,56]$, it is currently unlikely to be applied at such a high concentration $(20 \mu \mathrm{M})$ in the clinic. Importantly, dexmedetomidine at the concentration used in this study did not significantly affect NSC viability, as shown in a CCK-8 assay, which is based on dehydrogenase activity. The discrepancy in the results between cell viability and proliferation assays could be because the increase in cell number was insufficient to cause a significant increase in dehydrogenase activity in viable cells. Furthermore, we found that dexmedetomidine pretreatment reversed the ketamine-induced decrease in NSC viability and proliferation and the increase in NSC apoptosis, indicating that dexmedetomidine protected NSCs from ketamine-induced injury. These findings suggest that, even at a higher dose than that used in the clinic, dexmedetomidine does not injure NSCs, which provides a basis for the combination use of dexmedetomidine and ketamine in pediatric anesthesia.

Adult hippocampal NSCs cultured in vitro express all $\alpha_{2}$-adrenoceptor subtypes [57]. From 60 to 93 days after conception (E60-93) in macaque monkey fetuses, the ventricular and sub-

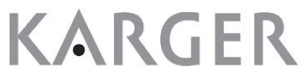


ventricular zones, where NSCs are mainly located, display high densities of $\alpha_{2}$-adrenergic receptors. These high densities of $\alpha_{2}$-adrenergic receptors remain near the ventricular surface long after all cortical neurons have been generated [58]. Furthermore, stimulation of $\alpha_{2}$-adrenergic receptors increases nestin-positive cells in the mouse cortex [59], inhibits hippocampal neural precursor cell activity, and decreases hippocampal neurogenesis [60]. Our study found that NSCs harvested from embryonic rats and grown in vitro expressed $\alpha_{2 \mathrm{~A}}$-adrenoceptor. As an $\alpha_{2}$-adrenoceptor agonist, the neuroprotective effects of dexmedetomidine in the developing brain have been investigated in many studies and have included mechanisms such as inhibition of calcium entry, scavenging of glutamate, activation of ERK1/2 via imidazoline receptors, activation of the Ras-Raf-pERK pathway via $\alpha_{2}$-adrenoceptor, reduction in NMDA receptor activation, and modulation of brain-derived neurotrophic factor expression [12, 61-64]. In addition, recent research has shown that the PI3K/Akt/GSK-3 $\beta$ signaling pathway is also involved in the protective effects of dexmedetomidine [23, 65]. As the mechanism underlying the protective effects of dexmedetomidine on ketamine-induced neurotoxicity remains unclear, our working hypothesis is that dexmedetomidine protects ketamine-injured NSCs by activating the PI3K/Akt/GSK-3 $\beta$ signaling pathway. In the present study, dexmedetomidine pretreatment reversed the ketamine-induced decrease in p-Akt and p-GSK-3 $\beta$ levels in NSCs, and this effect was blocked by the PI3K inhibitor LY294002. These results indicate that the PI3K/Akt/GSK-3 $\beta$ signaling pathway mediates the protective effects of dexmedetomidine on ketamine-induced neurotoxicity. Interestingly, Li et al. reported that the PI3K/Akt pathway participates in the dexmedetomidine-mediated protection against isoflurane-induced neuroapoptosis [23]. However, the upstream mechanisms of dexmedetomidine modulation of the PI3K/Akt/GSK-3 $\beta$ pathway need to be studied further.

In conclusion, dexmedetomidine pretreatment protects against ketamine-induced injury in NSCs by activating the PI3K/Akt/GSK-3 $\beta$ pathway. These findings provide a basis for the combination use of ketamine and dexmedetomidine in pediatric anesthesia. Before its application in clinics, the safety and efficacy of the ketamine and dexmedetomidine combination needs to be tested in animal experiments. Moreover, the effects of dexmedetomidine on the developing brain and long-term neurocognitive functions require in vivo studies. The mechanisms underlying the protective effects of dexmedetomidine on ketamine-induced neurotoxicity require further experimental and clinical investigation to address these important questions.

\section{Acknowledgements}

This work was supported by grants from: the National Natural Science Foundation of China (81071071, 81171247), Key Science and Technology Innovation Team of Shaanxi Province (2014KCT-22) and Science and Technology Development Project of Shaanxi Province (2013KTCL03-09). We would like to thank Prof. Malgorzata Garstka for critical reading of this manuscript and "ThinkScience" for English editing assistance.

\section{Disclosure Statement}

The authors declare that the research was conducted in the absence of any commercial or financial relationships that could be construed as a potential conflict of interests.

\section{References}

1 Scallet AC, Schmued LC, Jr SW, Grunberg N, Faustino PJ, Davis H, Lester D, Pine PS, Sistare F, Hanig JP: Developmental neurotoxicity of ketamine: morphometric confirmation, exposure parameters, and multiple fluorescent labeling of apoptotic neurons. Toxicol Sci 2004;81:364. 


\section{Cellular Physiology Cell Physiol Biochem 2018;47:1377-1388 \begin{tabular}{l|l} 
DOI: 10.1159/000490823 & $\begin{array}{l}\text { O 2018 The Author(s). Published by S. Karger AG, Basel } \\
\text { www.karger.com/cpb }\end{array}$ \\
\hline
\end{tabular}}

Lu et al.: Developmental Neurotoxicity and Neuroprotection

-2 Dong C, Rovnaghi CR, Anand KJ: Ketamine alters the neurogenesis of rat cortical neural stem progenitor cells. Crit Care Med 2012;40:2407-2416.

3 Lu C, Liu L, Chen Y, Ha T, Kelley J, Schweitzer J, Kalbfleisch JH, Kao RL, Williams DL, Li C: TLR2 ligand induces protection against cerebral ischemia/reperfusion injury via activation of phosphoinositide 3-kinase/Akt signaling. J Immunol 2011;187:1458.

4 Takadera T, Ishida A, Ohyashiki T: Ketamine-induced apoptosis in cultured rat cortical neurons. Toxicol Appl Pharmacol 2006;210:100-107.

5 Paule MG, Li M, Allen RR, Liu F, Zou X, Hotchkiss C, Hanig JP, Patterson TA, Jr SW, Wang C: Ketamine anesthesia during the first week of life can cause long-lasting cognitive deficits in rhesus monkeys. Neurotoxicol Teratol 2011;33:220.

6 Brambrink AM, Evers AS, Avidan MS, Farber NB, Smith DJ, Martin LD, Dissen GA, Creeley CE, Olney JW: Ketamine-induced neuroapoptosis in the fetal and neonatal rhesus macaque brain. Anesthesiology 2012;116:372-384.

7 Zou X, Patterson TA, Divine RL, Sadovova N, Zhang X, Hanig JP, Paule MG, Jr SW, Wang C: Prolonged exposure to ketamine increases neurodegeneration in the developing monkey brain. Int J Dev Neurosci 2009;27:727731.

8 Zou X, Patterson TA, Sadovova N, Twaddle NC, Doerge DR, Zhang X, Fu X, Hanig JP, Paule MG, Slikker W: Potential Neurotoxicity of Ketamine in the Developing Rat Brain. Toxicol Sci 2009;108:149-158.

-9 Winzer-Serhan UH, Raymon HK, Broide RS, Chen Y, ., Leslie FM: Expression of alpha 2 adrenoceptors during rat brain development--I. Alpha 2A messenger RNA expression. Neuroscience 1997;76:241.

10 Song ZM, Abouzeid 0, Fang YY: alpha2a adrenoceptors regulate phosphorylation of microtubule-associated protein-2 in cultured cortical neurons. Neuroscience 2004;123:405-418.

11 Winzer SU, Leslie F: Expression of alpha2A adrenoceptors during rat neocortical development. J Neurobiol 2015;38:259-269.

12 Dahmani S, Paris A, Jannier V, Hein L, Rouelle D, Scholz J, Gressens P, Mantz J: Dexmedetomidine increases hippocampal phosphorylated extracellular signal-regulated protein kinase 1 and 2 content by an alpha 2-adrenoceptor-independent mechanism: evidence for the involvement of imidazoline I1 receptors. Anesthesiology 2008;108:457-466.

13 Ma D, Hossain M, Rajakumaraswamy N, Arshad M, Sanders RD, Franks NP, Maze M: Dexmedetomidine produces its neuroprotective effect via the alpha 2A-adrenoceptor subtype. Eur J Pharmacol 2004;502:87-97.

14 Carney AE, Sanders RD, Garza KR, Mcgaha LA, Bean LJH, Coffee BW, Thomas JW, Cutler DJ, Kurtkaya NL, Fridovichkeil JL: Origins, distribution and expression of the Duarte-2 (D2) allele of galactose-1-phosphate uridylyltransferase. Hum Mol Genet 2009;18:1624.

15 Sanders RD, Xu J, Shu Y, Januszewski A, Halder S, Fidalgo A, Sun P, Hossain M, Ma D, Maze M: Dexmedetomidine attenuates isoflurane-induced neurocognitive impairment in neonatal rats. Anesthesiology 2009;110:10771085.

16 Sanders RD, Sun P, Patel S, M. LI, Maze M, D. MA: Dexmedetomidine provides cortical neuroprotection: impact on anaesthetic-induced neuroapoptosis in the rat developing brain. Acta Anaesthesiol Scand 2010;54:710.

17 Tosun Z, Akin A, Guler G, Esmaoglu A, Boyaci A: Dexmedetomidine-ketamine and propofol-ketamine combinations for anesthesia in spontaneously breathing pediatric patients undergoing cardiac catheterization. J Cardiothorac Vasc Anesth 2006;20:515-519.

-18 Selmi AL, Mendes GM, Figueiredo JP, Barbudoselmi GR, Lins BT: Comparison of medetomidine-ketamine and dexmedetomidine-ketamine anesthesia in golden-headed lion tamarins. Can Vet J 2004;45:: 481-485.

19 Levänen J, Mäkelä ML, Scheinin H: Dexmedetomidine premedication attenuates ketamine-induced cardiostimulatory effects and postanesthetic delirium. Anesthesiology 1995;82:1117-1125.

20 Brazil DP, Yang ZZ, Hemmings BA: Advances in protein kinase B signalling: AKTion on multiple fronts. Trends Biochem Sci 2004;29:233-242.

21 Shang Y, Wu Y, Yao S, Wang X, Feng D, Yang W: Protective effect of erythropoietin against ketamine-induced apoptosis in cultured rat cortical neurons: involvement of PI3K/Akt and GSK-3 beta pathway. Apoptosis 2007;12:2187-2195.

-22 Jovermengual T, Miyawaki T, Latuszek A, Alborch E, Zukin RS, Etgen AM: Acute estradiol protects CA1 neurons from ischemia-induced apoptotic cell death via the PI3K/Akt pathway. Brain Res 2010;1321:1-12. 


\section{Cellular Physiology Cell Physiol Biochem 2018;47:1377-1388 \begin{tabular}{l|l} 
DOI: 10.1159/000490823 & Ond Biochemistry 2018 The Author(s). Published by S. Karger AG, Basel \\
wwww.karger.com/cpb
\end{tabular}

Lu et al.: Developmental Neurotoxicity and Neuroprotection

23 Li Y, Zeng M, Chen W, Liu C, Wang F, Han X, Zuo Z, Peng S: Dexmedetomidine Reduces Isoflurane-Induced Neuroapoptosis Partly by Preserving PI3K/Akt Pathway in the Hippocampus of Neonatal Rats. Plos One 2014;9:e93639.

24 Chen X, Tian Y, Yao L, Zhang J, Liu Y: Hypoxia stimulates proliferation of rat neural stem cells with influence on the expression of cyclin D1 and c-Jun N-terminal protein kinase signaling pathway in vitro. Neuroscience 2010;165:705-714.

25 Zheng J, Zhang P, Li X, Lei S, Li W, He X, Zhang J, Wang N, Qi C, Chen X: Post-stroke estradiol treatment enhances neurogenesis in the subventricular zone of rats after permanent focal cerebral ischemia. Neuroscience 2013;231:82-90.

-26 Charriautmarlangue C, Margaill I, Plotkine M, Benari Y: Early Endonuclease Activation Following Reversible Focal Ischemia in the Rat Brain. J Cereb Blood Flow Metab 1995;15:385.

27 Ono K, Kagawa T, Tsumori T, Yokota S, Yasui Y: Morphological changes and cellular dynamics of oligodendrocyte lineage cells in the developing vertebrate central nervous system. Dev Neurosci 2001;23:346.

28 Bayer SA, Altman J, Russo RJ, Zhang X: Timetables of neurogenesis in the human brain based on experimentally determined patterns in the rat. Neurotoxicology 1993;14:83-144.

29 Huang H, Liu L, Li B, Zhao PP, Xu CM, Zhu YZ, Zhou CH, Wu YQ: Ketamine Interferes with the Proliferation and Differentiation of Neural Stem Cells in the Subventricular Zone of Neonatal Rats. Cell Physiol Biochem 2015;35:315.

-30 Wang C, Sadovova N, Hotchkiss C, Fu X, Scallet AC, Patterson TA, Hanig J, Paule MG, Slikker W: Blockade of N-Methyl-D-Aspartate Receptors by Ketamine Produces Loss of Postnatal Day 3 Monkey Frontal Cortical Neurons in Culture. Toxicol Sci 2006;91:192-201.

-31 Bai X, Yan Y, Canfield S, Muravyeva MY, Kikuchi C, Zaja I, Corbett JA, Bosnjak ZJ: Ketamine Enhances Human Neural Stem Cell Proliferation and Induces Neuronal Apoptosis Via Reactive Oxygen Species-Mediated Mitochondrial Pathway. Anesth Analg 2013;116:869-880.

-32 Luján R, Shigemoto R, Lópezbendito G: Glutamate and GABA receptor signalling in the developing brain. Neuroscience 2005;130:567-580.

-33 Ankarcrona M, Dypbukt JM, Bonfoco E, Zhivotovsky B, Orrenius S, Lipton SA, Nicotera P: Glutamate-induced neuronal death: a succession of necrosis or apoptosis depending on mitochondrial function. Neuron 1995;15:961-973.

-34 Kitayama T, Yoneyama M, Tamaki K, Yoneda Y: Regulation of neuronal differentiation by N -methyl- D -aspartate receptors expressed in neural progenitor cells isolated from adult mouse hippocampus. J Neurosci Res 2004;76:599-612.

35 Deisseroth K, Singla S, Toda H, Monje M, Palmer TD, Malenka RC: Excitation-neurogenesis coupling in adult neural stem/progenitor cells. Neuron 2004;42:535-552.

-36 Kitayama T, Yoneyama M, Yoneda Y: Possible regulation by N-methyl-d-aspartate receptors of proliferative progenitor cells expressed in adult mouse hippocampal dentate gyrus. J Neurochem 2003;84:767.

-37 Joo JY, Kim BW, Lee JS, Park JY, Kim S, Yun YJ, Lee SH, Lee SH, Rhim H, Son H: Activation of NMDA receptors increases proliferation and differentiation of hippocampal neural progenitor cells. J Cell Sci 2007;120:1358.

-38 Kitamura T, Mishina M, Sugiyama H: Enhancement of neurogenesis by running wheel exercises is suppressed in mice lacking NMDA receptor epsilon 1 subunit. Neurosci Res 2003;47:55.

39 Li M, Zhang DQ, Wang XZ, Xu TJ: NR2B-containing NMDA receptors promote neural progenitor cell proliferation through CaMKIV/CREB pathway. Biochem Biophys Res Commun 2011;411:667-672.

$\checkmark 40$ Chakraborty A, Murphy S, Coleman N: The role of NMDA receptors in neural stem cell proliferation and differentiation. Stem Cells Dev 2017;26:

41 Sutton G, Chandler LJ: Activity-dependent NMDA receptor-mediated activation of protein kinase B/Akt in cortical neuronal cultures. J Neurochem 2002;82:1097-1105.

-42 Habas A, Kharebava G, Szatmari E, Hetman M: NMDA neuroprotection against a phosphatidylinositol-3 kinase inhibitor, LY294002 by NR2B-mediated suppression of glycogen synthase kinase-3beta-induced apoptosis. J Neurochem 2006;96:335-348.

43 Chan MH, Chiu PH, Lin CY, Chen HH: Inhibition of glycogen synthase kinase-3 attenuates psychotomimetic effects of ketamine. Schizophr Res 2012;136:96-103.

-44 Li J, Wu H, Xue G, Wang P, Hou Y: 17ß-Oestradiol Protects Primary-Cultured Rat Cortical Neurons from Ketamine-Induced Apoptosis by Activating PI3K/Akt/Bcl-2 Signalling. Basic Clin Pharmacol Toxicol 2013;113:411-418. 


\section{Cellular Physiology Cell Physiol Biochem 2018;47:1377-1388

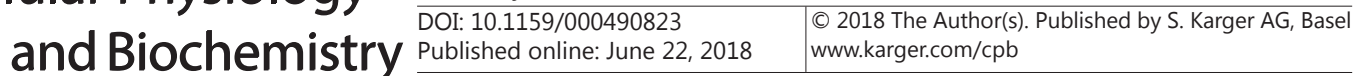

Lu et al.: Developmental Neurotoxicity and Neuroprotection

45 Beurel E, Song L, Jope RS: Inhibition of glycogen synthase kinase-3 is necessary for the rapid antidepressant effect of ketamine in mice. Mol Psychiatry 2011;16:1068.

-46 Liu JR, Baek C, Han XH, Shoureshi P, Soriano SG: Role of glycogen synthase kinase-3 $\beta$ in ketamine-induced developmental neuroapoptosis in rats. Br J Anaesth 2013;110:3-9.

47 Lahti AC, Holcomb HH, Medoff DR, Tamminga CA: Ketamine activates psychosis and alters limbic blood flow in schizophrenia. Neuroreport 1995;6:869-872.

-48 Zhu YM, Wang CC, Chen L, Qian LB, Ma LL, Yu J, Zhu MH, Wen CY, Yu LN, Yan M: Both PI3K/Akt and ERK1/2 pathways participate in the protection by dexmedetomidine against transient focal cerebral ischemia/reperfusion injury in rats. Brain Res 2013;1494:1.

49 Goyagi T, Tobe Y: Dexmedetomidine improves the histological and neurological outcomes $48 \mathrm{~h}$ after transient spinal ischemia in rats. Brain Res 2014;1566:24-30.

50 Kakinohana M, Oshiro M, Saikawa S, Nakamura S, Higa T, Davison KJ, Marsala M, Sugahara K: Intravenous infusion of dexmedetomidine can prevent the degeneration of spinal ventral neurons induced by intrathecal morphine after a noninjurious interval of spinal cord ischemia in rats. Anesth Analg 2007;105:1086-1093.

51 Liao Z, Cao D, Han X, Liu C, Peng J, Zuo Z, Wang F, Li Y: Both JNK and P38 MAPK pathways participate in the protection by dexmedetomidine against isoflurane-induced neuroapoptosis in the hippocampus of neonatal rats. Brain Res Bull 2014;107:69-78.

52 Duan X, Li Y, Zhou C, Huang L, Dong Z: Dexmedetomidine provides neuroprotection: impact on ketamineinduced neuroapoptosis in the developing rat brain. Acta Anaesthesiol Scand 2014;58:1121-1126.

53 Peng M, Wang YL, Wang CY, Chen C: Dexmedetomidine attenuates lipopolysaccharide-induced proinflammatory response in primary microglia. J Surg Res 2013;179:219-225.

54 Lai YC, Tsai PS, Huang CJ: Effects of dexmedetomidine on regulating endotoxin-induced up-regulation of inflammatory molecules in murine macrophages. J Surg Res 2009;154:212-219.

-55 Mason KP, Zurakowski D, Zgleszewski SE, Robson CD, Carrier M, Hickey PR, Dinardo JA: High dose dexmedetomidine as the sole sedative for pediatric MRI. Paediatr Anaesth 2008;18:403-411.

-56 Pandharipande PP, Pun BT, Herr DL, Maze M, Girard TD, Miller RR, Shintani AK, Thompson JL, Jackson JC, Deppen SA: Effect of sedation with dexmedetomidine vs lorazepam on acute brain dysfunction in mechanically ventilated patients: the MENDS randomized controlled trial. JAMA 2007;298:2644-2653.

57 Yanpallewar SU, Fernandes K, Marathe SV, Vadodaria KC, Jhaveri D, Rommelfanger K, Ladiwala U, Jha S, Muthig V, Hein L: $\alpha 2$-adrenoceptor blockade accelerates the neurogenic, neurotrophic, and behavioral effects of chronic antidepressant treatment. J Neurosci 2010;30:1096-1109.

58 Michael SLPD, Rakic P: Neurotransmitter receptors in the proliferative zones of the developing primate occipital lobe. J Comp Neurol 1995;360:393-402.

-59 Vadodaria KC, Yanpallewar SU, Vadhvani M, Toshniwal D, Liles LC, Rommelfanger KS, Weinshenker D, Vaidya VA: Noradrenergic regulation of plasticity marker expression in the adult rodent piriform cortex. Neurosci Lett 2017;644:76-82.

60 Jhaveri DJ, Nanavaty I, Prosper BW, Marathe S, Husain BF, Kernie SG, Bartlett PF, Vaidya VA: Opposing effects of $\alpha 2$ - and $\beta$-adrenergic receptor stimulation on quiescent neural precursor cell activity and adult hippocampal neurogenesis. Plos One 2014;9:e98736.

61 Paris A, Mantz J, Tonner PH, Hein L, Brede M, Gressens P: The effects of dexmedetomidine on perinatal excitotoxic brain injury are mediated by the alpha2A-adrenoceptor subtype. Anesth Analg 2006;102:456-461.

62 Degos V, Charpentier TL, Chhor V, Brissaud O, Lebon S, Schwendimann L, Bednareck N, Passemard S, Mantz J, Gressens P: Neuroprotective Effects of Dexmedetomidine against Glutamate Agonist-induced Neuronal Cell Death Are Related to Increased Astrocyte Brain-derived Neurotrophic Factor Expression. Anesthesiology 2013;118:1123-1132.

63 Laudenbach V, Mantz J, Lagercrantz H, Desmonts JM, Evrard P, Gressens P: Effects of alpha(2)-adrenoceptor agonists on perinatal excitotoxic brain injury: comparison of clonidine and dexmedetomidine. Anesthesiology 2002;96:134.

64 Jevtovictodorovic V, Hartman RE, Izumi Y, Benshoff ND, Dikranian K, Zorumski CF, Olney JW, Wozniak DF: Early exposure to common anesthetic agents causes widespread neurodegeneration in the developing rat brain and persistent learning deficits. J Neurosci 2003;23:876.

65 Do SH, Park SJ, Shin HJ, Paik HS, Zuo Z, Yoon HJ, Ryu JH: Dexmedetomidine increases the activity of excitatory amino acid transporter type 3 expressed in Xenopus oocytes: the involvement of protein kinase C and phosphatidylinositol 3-kinase. Eur J Pharmacol 2014;738:8-13. 